\title{
Serial Assessment of Biochemical Parameters of Red Cell in the Blood Unit Segments Kept At $4^{0}$
}

\section{Deva Japa A*, Mahpaekar M and Sanjeeth $\mathrm{P}$ \\ Senior Research Scientist, DDMM Heart Institute, India}

*Corresponding author: Deva Japa Ajith, Department of Pathology \& Blood bank, DDMM Heart Institute, Mission Road, Nadiad-387002, India, Tel: 91-9426562802;

Email: devajapa@ddmmheart.org

\section{Research Article \\ Volume 3 Issue 2}

Received Date: November 14, 2019

Published Date: November 29, 2019

DOI: $10.23880 /$ hij-16000149

\section{Abstract}

The development of blood storage systems allowed donation and transfusion to be separated in time and space. This separation has permitted the regionalization of donor services with subsequent economies of scale and improvements in the quality and availability of blood products. However, the availability of storage raises the question of how long blood products can and should be stored and how long they are safe and effective. During blood bank cold storage, red cells progressively lose deformability and elasticity due to irreversible changes in the cell membrane.

Aim: The aim of this study is to assess the relative importance of these diverse biochemical changes in the stored RBC.

Methodology: The donors of the blood units included in this study were healthy by all parameters considered for blood banking. Whole blood of $450 \mathrm{ml}$ collection bag unit containing 63ml CPD/SAGM (which has a permissible life span of 42 days) and containing $63 \mathrm{ml}$ of CPDA (which has a life span of 35 days) were subjected to standard component separation. A total of 35 consecutively separated blood bags with 7 segments each were studied. Each segment from the Packed Red Cell unit was removed on days $0,7,14,21,28,35$ and 42 of PRBC storage, were investigated. The biochemical and hematological parameters such as pH, Lactate, Sr.Potassium, Plasma Haemoglobin, Heamoglobin and Heamatocrit were analyzed in fully automated analyzer.

Results and Analysis: RBC unit characteristics just before storage on Day 0 pH $\left(37^{\circ} \mathrm{C}\right) 7.03+\_0.94(7.20-6.79) \mathrm{Hb}$ (mg/dL) 15.3 +_2.2 (17.9-13.9),Plasma Hemoglobin 3.1+-1.2 gm/dl Lactate (mmol/L) 2 +_ 1.4 (1.3-3.1)Potassium(K) (mmol/L)1.7+-1.2. Extracellular K and Lactate showed a constant increase as the bags aged. Hemoglobin and Haematocrit levels did not change appreciably throughout the storage period.

Conclusion: The older RBC may have adverse effects like increase in potassium, lactate but the transfusion department can help the clinician by knowing the patient's clinical status as well as the age, critical variables like Sepsis by issuing the recent dated Blood units.

Keywords: Red Blood Cell; Storage Lesion; Membrane Deformability 
Abbreviations: RBC: Red Blood Cells.

\section{Introduction}

The development of blood storage systems allowed donation and transfusion to be separated in time and space. This separation has permitted the regionalization of donor services with subsequent economies of scale and improvements in the quality and availability of blood products. However, the availability of storage raises the question of how long blood products can and should be stored and how long they are safe and effective. During blood bank cold storage, red cells progressively lose deformability and elasticity due to irreversible changes in the cell membrane. Morphologically this is observed as progressive irreversible formation of sphero-echinocytes. Due to the gradual decomposition of RBCs and as a result of the accumulation of products of cellular metabolism, i.e. anaerobic glycolysis, the biochemical composition of $\mathrm{RBC}$ concentrates changes. Although it is not clear to what extent anaerobic storage prevents morphological or biochemical changes. During refrigerated storage, RBCs become progressively damaged by storage lesions. Clinical implications collectively known as the RBC storage lesion, is in part related to bioreactive substances released by leucocytes in the storage medium, such as histamine, lipids, and cytokines, which may exert direct effects on recipients [1], presumably due to structural or functional changes in red blood cells (RBC) that occur during storage [2]. We have very scarce study to assess the relative importance of these diverse biochemical changes in the stored RBC. Due to the gradual decomposition of RBCs and as a result of the accumulation of products of cellular metabolism, the biochemical composition of RBC concentrates undergoes changes [3]. Although it is not clear to what extent, the anaerobic storage prevents morphological or biochemical changes at low temperature.

\section{Methodology}

The donors of the blood units included in this study were healthy by all parameters considered for blood banking. Whole blood of $450 \mathrm{ml}$ collection bag unit containing $63 \mathrm{ml}$ CPD/SAGM (which has a permissible life span of 42 days) and containing $63 \mathrm{ml}$ of CPDA (which has a life span of 35 days) were subjected to standard component separation. A total of 35 consecutively separated blood bags with 7 segments each were studied. Each segment from the Packed Red Cell unit was removed on days $0,7,14,21,28,35$ and 42 of PRBC storage, were investigated. The biochemical and hematological parameters such as $\mathrm{pH}$, Lactate, Sr.Potassium, Plasma Haemoglobin, Heamoglobin and Heamatocrit were analyzed in fully automated analyzer [4-6].

\section{Results and Analysis}

RBC unit characteristics just before storage on Day 0 $\mathrm{pH}\left(37^{\circ} \mathrm{C}\right) 7.03+0.94(7.20-6.79) \mathrm{Hb}(\mathrm{mg} / \mathrm{dL}) 15.3+2.2$ (17.9-13.9),Plasma Hemoglobin 3.1+-1.2 gm/dl Lactate $(\mathrm{mmol} / \mathrm{L}) 2$ +_ $1.4(1.3-3.1)$ Potassium(K) $(\mathrm{mmol} / \mathrm{L}) 1.7+-$ 1.2 (Tables $1 \& 2$ \& Figures $1 \& 2$ ).

\begin{tabular}{|c|c|c|c|c|c|c|c|c|c|}
\hline \multirow{2}{*}{ Biochemical factors } & \multicolumn{7}{|c|}{ Mean } & \multirow{2}{*}{$F$ value } & \multirow{2}{*}{$P$ value } \\
\hline & & $7^{\text {th }}$ day & $14^{\text {th }}$ day & $21^{\text {st }}$ day & $28^{\text {th }}$ day & $35^{\text {th }}$ day & 42 ${ }^{\text {nd }}$ day & & \\
\hline Plasma $\mathrm{Hb}$ & 3.13 & 3.26 & 3.26 & 3.4 & 3.78 & 3.95 & 3.62 & 2.06 & 0.06 \\
\hline Haemoglobin & 12.85 & 11.73 & 11.09 & 11 & 10.09 & 10.47 & 9.78 & 12.78 & 0 \\
\hline Haematocrit & 38.91 & 35.74 & 33.74 & 33.29 & 30.86 & 31.74 & 29.6 & 12.73 & 0 \\
\hline
\end{tabular}

Table 1: Biochemical Factors.

\begin{tabular}{|c|c|c|c|c|c|c|c|}
\hline $\mathbf{p H}$ & $\mathbf{0}$ day & $\mathbf{7}^{\text {th }}$ day & $\mathbf{1 4}^{\text {th }}$ day & $\mathbf{2 1}^{\text {st }}$ day & $\mathbf{2 8}^{\text {th }}$ day & $\mathbf{3 5}^{\text {th }}$ day & $\mathbf{4 2}^{\text {nd }}$ day \\
\hline Normal & 0 & 0 & 0 & 0 & 0 & 0 & 0 \\
\hline Abnormal & 37 & 37 & 37 & 37 & 37 & 36 & 37 \\
\hline Lactate & $\mathbf{0}$ day & $7^{\text {th }}$ day & $\mathbf{1 4}^{\text {th }}$ day & $\mathbf{2 1}^{\text {st }}$ day & $\mathbf{2 8}^{\text {th }}$ day & $\mathbf{3 5}^{\text {th }}$ day & $\mathbf{4 2}^{\text {nd }}$ day \\
\hline Normal & 28 & 0 & 0 & 0 & 0 & 0 & 0 \\
\hline Abnormal & 9 & 37 & 37 & 37 & 37 & 36 & 37 \\
\hline Serum K & $\mathbf{0}$ day & $7^{\text {th }}$ day & $\mathbf{1 4}^{\text {th }}$ day & $\mathbf{2 1}^{\text {st }}$ day & $\mathbf{2 8}^{\text {th }}$ day & $\mathbf{3 5}^{\text {th }}$ day & $\mathbf{4 2}^{\text {nd }}$ day \\
\hline Normal & 1 & 0 & 0 & 0 & 0 & 0 & 0 \\
\hline Abnormal & 36 & 37 & 37 & 37 & 37 & 36 & 37 \\
\hline
\end{tabular}

Table 2: Extracellular K and Lactate showed a constant increase as the bags aged. Hemoglobin and Haematocrit levels did not change appreciably throughout the storage period. 


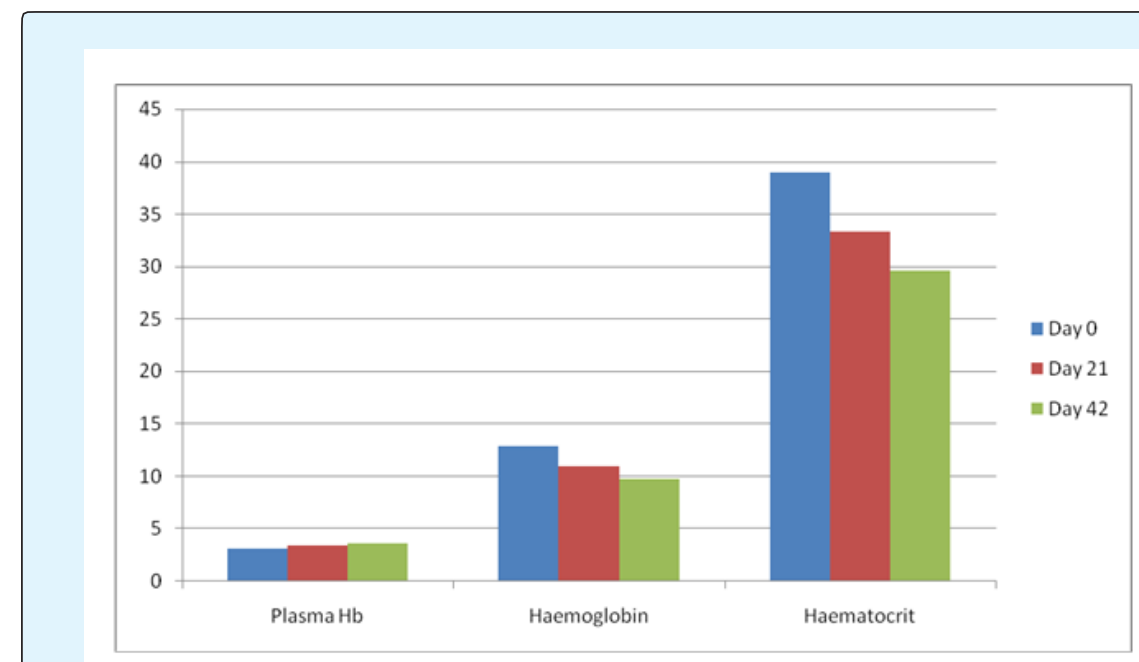

Figure 1: Hematological Parameters analysis in different duration.

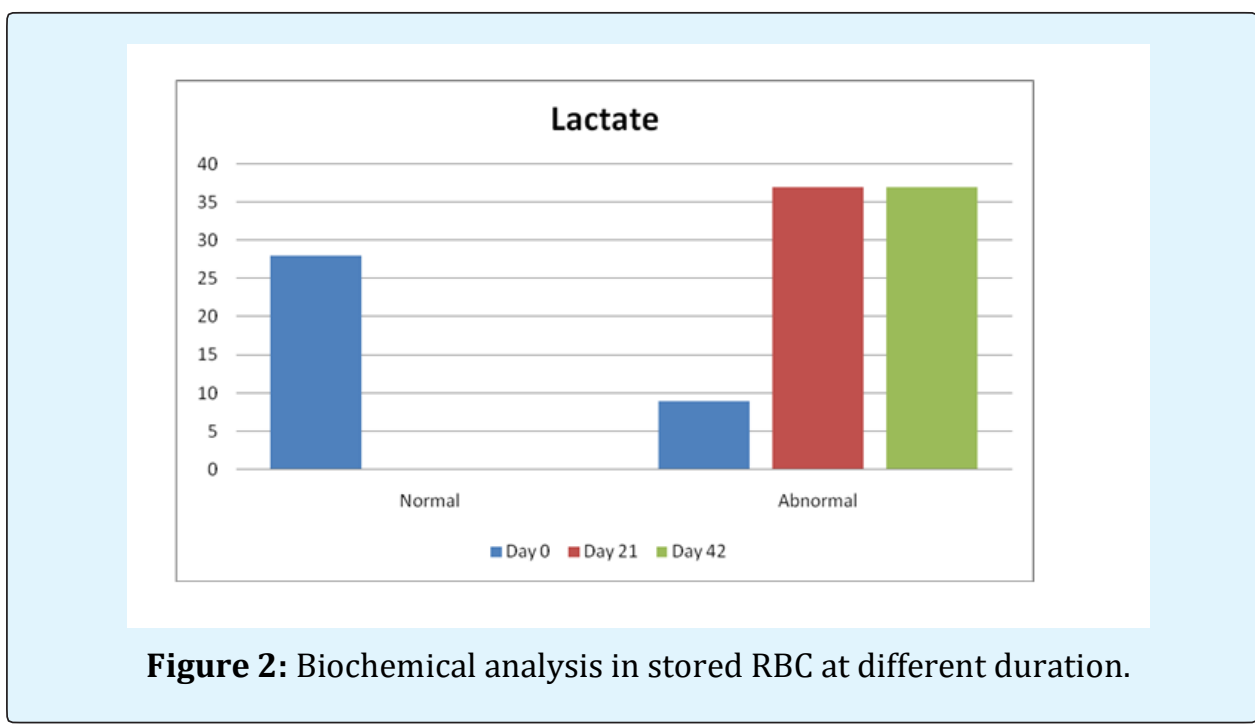

\section{Conclusion}

Clinical implications collectively known as the RBC storage lesion released by leucocytes in the storage medium, such as lactate, histamine, lipids and cytokines, which may exert direct effects on recipients, presumably due to structural or functional changes in RBC that occur during storage. But this study suggests that older RBC may have adverse effects like increase in potassium, lactate but the transfusion department can help the clinician by knowing the patient's clinical status as well as the age, critical variables like Sepsis by issuing the recent dated Blood units.

\section{References}

1. Wagner G, Chiu D, Qju J, Heath RH, Lubin BH (1987) Spectrin oxidation correlates with membrane vesiculation in stored RBCs. Blood 69(6): 1777-1781.

2. D'Alessandro A, D'Amici G, Vaglio S, Zolla L (2012) Timecourse investigation of SAGM-stored leukocytefiltered erthrocyte concentrates: from metabolism to proteomics. Haematologica 97(1): 107-115. 
3. Koch C, Li L, Sessler D, Figueroa P, Hoeltge GA, et al. (2008) Duration of red-cell storage and complications after cardiac surgery. N Engl J Med 358: 1229-1239.

4. Dzik W (2008) Fresh blood for everyone? Balancing availability and quality of stored RBCs. Transfus Med 18(4): 260-265.
5. Hebert PC, Chin-Yee I, Fergusson D, Blajchman M, Martineau R, et al. (2005) A pilot trial evaluating the clinical effects of prolonged storage of red cells. Anesth Analg 100(5): 1433-1438.

6. Hess JR, Hill HR, Oliver CK, Lippert LE, Rugg N, et al. (2003) Twelve-week RBC storage. Transfusion 43(7): 867-872. 